\title{
A comunidade caiçara da Enseada da Baleia e a sua luta pelo território - Cananéia (SP)
}

\author{
The 'Enseada da Baleia' caiçara community and its struggle for the territory - Cananéia (SP)
}

\author{
Juliana Greco Yamaoka ${ }^{1}$ \\ Tatiana Mendonça Cardoso ${ }^{2}$ \\ Valdir Frigo Denardin ${ }^{3}$ \\ Alan Ripoll Alves ${ }^{4}$
}

\begin{abstract}
Resumo
Os povos e as comunidades tradicionais têm profunda relação com seu território no que tange à manutenção de sua organização social, política e cultural. Muitas são as ameaças que se impõem a eles, as quais vão das diversas formas hegemônicas de desenvolvimento aos desafios vivenciados a partir de questões ambientais. No caso dos caiçaras presentes na Mata Atlântica, não é diferente. Para tanto, buscou-se o estudo de caso da comunidade caiçara da Enseada da Baleia, que resistiu para permanecer na Ilha do Cardoso, em Cananéia-SP, mesmo após um processo erosivo que inviabilizou sua presença no local. Este trabalho teve como objetivo apresentar o papel das mulheres no processo de resistência para a permanência no Parque Estadual da Ilha do Cardoso. Para isso, foram realizados grupos focais e entrevistas semiestruturadas com as famílias da Enseada e parte de seus parceiros, além de pesquisas em fontes bibliográficas e documentais. Como resultado constatou-se que as principais vias de resistência que proporcionaram a permanência na Ilha do Cardoso ocorreram a partir do Grupo de Mulheres Artesãs da Enseada da Baleia (MAE), que influenciou a organização de algumas atividades socioprodutivas e a sua continuidade no local. Casos como estes, que poderiam se tornar invisibilizados pela sua dimensão e proposta, podem ser apresentados como alternativas para a compreensão de um pluriverso, conceito que defende um mundo onde coexistam várias formas de mundo, simultaneamente.
\end{abstract}

Palavras-chave: Economia Solidária; organização feminina; territorialidade; povos e comunidades tradicionais.

\footnotetext{
Abstract

Traditional peoples and communities have a deep relationship with their territory, for the maintenance of their social, political and cultural organization. There are many threats that they come across, since the various hegemonic forms of development to the challenges experienced by natural issues. In the case of caiçara communities in the Atlantic Forest, it is no different. For this purpose, the case study of the caiçara community of Enseada da Baleia, that fought to remain in the Cardoso island, Cananéia$\mathrm{SP}$, even after an erosive process that made impossible their stay where they used to live. This work

${ }^{1}$ Mestra em Desenvolvimento Territorial Sustentável pela Universidade Federal do Paraná - Setor Litoral. E-mail: julianagreco82@gmail.com.

${ }^{2}$ Graduanda em Ciências Sociais na Universidade de Franca (UNIFRAN), moradora da comunidade da Enseada da Baleia e integrante do Grupo de Mulheres Artesãs da Enseada da Baleia (MAE). E-mail: enseadadabaleia@gmail.com.

3 Doutor em Ciências Sociais (CPDA/UFRRJ). Professor dos Programas de Pós-Graduação em Desenvolvimento Territorial Sustentável (PPGDTS/UFPR) e Meio Ambiente e Desenvolvimento (PPGMADE/UFPR). E-mail: valdirfd@yahoo.com.br.

${ }^{4}$ Doutor em Meio Ambiente e Desenvolvimento (PPGMADE/UFPR). Professor do Programa de Pós-Graduação em Desenvolvimento Territorial Sustentável (PPGDTS/UFPR). E-mail: alanripoll@ufpr.br.
} 
aimed to present the role of women in the process of resistance to the permanence in the Cardoso Island State Park. For that, focus groups and semi-structured interviews were conducted with Enseada da Baleia families and some of their partners, as well as bibliographical and documentary sources. As a result, the main resistance pathways that provided their permanence in the Cardoso island. The Women's Artisan Group of Enseada da Baleia (MAE - Mulheres Artesãs da Enseada) has influenced the organization of some socioproductive activities and the strategic process to remain in the Cardoso Island. Cases like these, which could be undermined by its dimension and world proposal, but deserve to be presented as alternatives to understand a pluriverse, a concept that defends a world where several forms of world coexist simultaneously.

Keywords: Solidarity Economy; female organization; territoriality; traditional peoples and communities.

\section{Introdução}

No dia 20 de janeiro de 1949, nasce a era do desenvolvimento no mundo, que se apresenta através de uma campanha global para marcar a posição hegemônica dos Estados Unidos, após a Segunda Guerra Mundial. Um discurso do Presidente Truman, que pretendia levar seus avanços e progresso industrial para as áreas subdesenvolvidas, ressignificaria o conceito de desenvolvimento, ao referir-se ao modelo norte-americano, criando uma nova percepção do "eu" e do "outro" subitamente. Nesse dia, aquela maioria heterogênea seria enviada ao fim da fila, “[...] dois bilhões de pessoas passaram a ser subdesenvolvidas" (ESTEVA, 2000, p. 59-60). Neste contexto, o desenvolvimento carrega em si a noção de progresso, que acredita que a História caminha para uma direção em que o futuro será a superação do presente, e que tem como princípios: acreditar no valor do passado, a superioridade da civilização ocidental, aceitação do valor do crescimento (econômico e tecnológico) e a fé na razão (RODRIGUEZ; SILVA, 2016, p. 33). Ao mesmo tempo em que não haveria possibilidade de seguir o exemplo de consumo, em um mundo finito, essa "modernidade" se tornaria um desafio a todas as outras formas de vida que não se enquadrariam nesse padrão.

Com outras racionalidades, encontram-se, por exemplo, os povos e comunidades tradicionais e estima-se que estes, “[...] no Brasil, perfazem um total aproximado de 25 milhões de pessoas [...] e ocupam aproximadamente $1 / 4$ do território nacional" (MDS, 2009, p. 11), interagindo diretamente com o regime de propriedade vigente de terras púbicas ou privadas, que "[...] são presididas pela lógica capitalista e individualista" (LITTLE, 2004, p. 258-259), altamente concentradas. A ausência de instrumentos capazes de reconhecer as terras tradicionalmente ocupadas, no caso de caiçaras e outros povos tradicionais, são apenas parte do desafio, já que a pauta "território" carrega consigo a possibilidade de garantir a existência de outras racionalidades, “[...] dentro do mundo relacional, a 
defesa do território, da vida e da terra comunitária é uma mesma causa" (ESCOBAR, 2016, p. 20, tradução nossa).

Dentro deste contexto de comunidades tradicionais que resistem para a sua permanência em territórios tradicionalmente ocupados, estão as comunidades caiçaras da Ilha do Cardoso, onde estima-se que viviam aproximadamente 500 famílias no início da década de 1960 (GADELHA, 2008; NUPAUB, 2016), quando a Ilha foi transformada em parque estadual (Parque Estadual da Ilha do Cardoso - PEIC), no ano de 1962. Não foi apenas a implantação da unidade de conservação que pressionou as populações a saírem de suas terras, registrou-se através das memórias de moradores da Enseada da Baleia: dificuldades para a permanência devido à ausência de atividades geradoras de renda, impossibilidade de seguir com as roças e regulamentação de outras atividades produtivas, ausência de escolas, especulação imobiliária, pressões de retomada da terra pela União, implantação de empreendimentos com fins mercantis, perda de lideranças e um processo erosivo como vetores que pressionaram a comunidade em determinada época a resistirem para permanecer em suas terras. Somadas a outras especificidades locais, resultaram na permanência de apenas 389 moradores tradicionais, em 140 unidades habitacionais (CARVALHO; SCHMITT, 2012).

No caso específico da comunidade caiçara da Enseada da Baleia, o vetor de pressão que os obrigou a realocação foi um acentuado processo erosivo que ocorreu nas últimas décadas na área onde estava situada, levando à realocação das famílias em 2017. A ausência de instrumentos legais que lhes garantissem a terra foi atenuada pela presença de um plano de manejo que reconhecia as comunidades tradicionais, mesmo que em uma unidade de conservação (UC) de proteção integral, que legalmente restringe a permanência de moradores. Obteve-se a licença para desmate, mas para que a realocação ocorresse de fato e cumprisse com os anseios das famílias, foram percorridas diversas vias de resistência que dessem conta do processo de realocação para uma nova área dentro do PEIC, que vem sendo chamada de Nova Enseada. A realocação das onze famílias, para a Nova Enseada a partir de 2017, uma nova área dentro de uma unidade de conservação de proteção integral e todos os desafios decorrentes desse processo motivaram a pesquisa.

Percebeu-se que um ponto determinante foi a atuação das mulheres da comunidade no processo de resistência. Neste caso, como resposta a uma crise que se instalara com o falecimento do patriarca da família em 2010, o Grupo de Mulheres Artesãs da Enseada da Baleia (MAE) foi formado, criando condições para esta permanência. Auto-organizado dentro dos princípios da economia solidária, o MAE foi determinante para que esta realocação ocorresse para uma área escolhida pela comunidade, de modo que tivesse condições de manter em partes seu modo de vida. O texto foca na compreensão do processo empreendido pelas mulheres e, para isso, a resistência foi selecionada como 
a categoria de análise dentro do mesmo. Neste contexto a pesquisa teve como objetivo apresentar o papel das mulheres no processo de resistência que contribuiu para a permanência das famílias da Enseada da Baleia no Parque Estadual da Ilha do Cardoso.

\section{Resistência: aproximações iniciais}

As formas cotidianas de resistência, segundo Scott (2011), são aquelas voltadas a mitigar ou rejeitar demandas de superiores ou levar adiante reivindicações das classes que representam. Estariam relacionadas com a luta de classes e teriam como pautas: apropriação da terra, trabalho, impostos, renda etc. A resistência cotidiana é interpretada como informal, por vezes dissimulada e preocupada com ganhos imediatos, sendo a muitas vezes a única opção para classes subalternas. Difere, portanto, da política institucionalizada, que em seu ponto de vista é formal, ostensiva e preocupada com mudanças sistemáticas. Apesar da relevância deste autor para a discussão da categoria de pesquisa, a abordagem seria insuficiente para a compreensão do fenômeno estudado, portanto alguns críticos a esta teoria deram subsídios para analisar a categoria.

O primeiro deles é Viola-Recasens (2008), que reconhece a influência de Scott em diversas áreas e, também, os benefícios de conceber outras formas de resistência além das que ocorrem em organizações formais. $\mathrm{O}$ autor se preocupa em tratar o que entende como ações desorganizadas, sem coordenação, líderes, manifestos ou programas, como algo contínuo, que se articula ao longo do tempo. A crítica é feita ao fato de Scott (2011) compreender que as revoltas organizadas têm fortes chances de fracassarem com os sistemas de opressão. Seria, portanto, uma visão “[...] excessivamente unidimensional e reducionista da conduta e da consciência humana" (VIOLA-RECASENS, 2008, p. 68). Outro ponto destacado é a interpretação das intenções dos atores sociais. Ações como roubo e evasão fiscal, poderiam não ser atos conscientes de resistências, mas atos de sobrevivência. Além de problemas com os exemplos dos casos apresentados, que foram comparados com pesquisas mais aprofundadas.

A fim de ampliar o debate da categoria, Porto-Gonçalves (2016) afirma que a América Latina, em função das investidas hegemônicas (descritas por ele como "tormenta sistêmica mundial"), provocariam a emergência de alternativas sociais pela defesa de terra e território, baseadas em visões alternativas a este modo de desenvolvimento. As resistências viriam de populações locais, de espaços de diversidade socio-cultural-ambiental e espaços de resistências às políticas dominantes. Seriam formas de r-existência, que apontam para fenômenos mais amplos do que a resistência anteriormente 
proposta, indicando uma forma de existir, uma matriz de racionalidade que age e reage às circunstâncias a partir de um topoi (um lugar comum) geográfico e epistêmico. Desse modo, justificando a importância de resistências, r-existências das epistemes e do território (onde a terra é o foco), em função da ordem moderno-colonial e do significado da natureza para a reprodução de qualquer sociedade (a natureza é tida pelo pensamento antropocentrista europeu como passível de dominação).

A r-existência proposta por Porto-Gonçalves (2006) dialoga perfeitamente com a compreensão de Baschet (2012) acerca do tema, que aponta que o conceito pode variar de acordo com o contexto, mas que se aplicam a situações desfavoráveis, “[...] frente a uma dominação que pretende arrastar com tudo, os grupos de resistência lutam inclusive para defender sua própria existência" (BASCHET, 2012, p. 2).

Por fim, encontrou-se em Mafra (2018) as vias de resistência e enfrentamento para uma análise mais profunda do caso estudado. Esse autor afirma que a resistência pode se dar em três níveis: a) as ações coletivas, através da estruturação de movimentos sociais organizados e com objetivo comum; b) outras formas de organizações populares; e c) as ações individuais ou de pequenas parcelas oprimidas, realizadas cotidianamente.

Como pano de fundo, o conceito de terras tradicionalmente ocupadas que se torna preceito jurídico a partir dos embates da Constituinte de $1988^{5}$, e que vem ampliando seus significados a partir de junho de 2002, com a ratificação da Convenção 169 da OIT, de junho de 1989, através do Decreto Legislativo $\mathrm{n}^{\circ}$ 143. Esta Convenção reconhece a autoidentificação das identidades, sejam elas indígenas ou tribais (através do Art. 2), os direitos de propriedade ou posse sobre as terras que tradicionalmente ocupam (através do art. 14) e sobre o direito ao retorno a suas terras tradicionais, quando deixarem de existir as causas que motivaram o traslado e reassentamento (com Art. 16). Esse direito abriga um sem-número de situações distribuídas pelo Brasil, que resultaram em deslocamento de populações inteiras por diversos motivos pelos quais as terras são exploradas com fins mercantis (ALMEIDA, 2004).

Aponta-se também para o conceito de pluriverso, que se alinha ao conceito anterior na busca de compreender outras racionalidades, como pontua Escobar (2013), que se contrapõe ao modelo de mundo globalizado, em que só existe uma única racionalidade e se alinha com os territórios de povos e comunidades tradicionais em que existem outros mundos, existem outras formas de ver a vida e

\footnotetext{
${ }^{5}$ Segundo MPF (2014, p. 35-36), os artigos da Constituição, que orientam sobre as terras tradicionais são os Art. 231 e Art. 68, para o caso de povos indígenas e quilombolas. Mas reconhece como territórios tradicionais, "os espaços necessários à reprodução cultural, social e econômica dos povos e comunidades tradicionais".
} 
cosmovisões. "Um mundo onde caibam muitos mundos" (ESCOBAR, 2013, não paginado, tradução nossa), definição dada pelos zapatistas para um mundo pluralista.

\section{Metodologia}

O trabalho tem cunho qualitativo exploratório e foi realizado com as famílias da comunidade da Enseada da Baleia, que se realoca para a Nova Enseada, localizadas na Ilha do Cardoso, CananéiaSP, município que está localizado a $270 \mathrm{~km}$ da capital paulista e 250 da capital paranaense.

A Ilha do Cardoso (FIGURA 1) tem uma área total de $151 \mathrm{~km}^{2}$ e está dividida em compartimentos distintos, uma área de relevo montanhoso e outra de planícies costeiras, onde está a restinga do Ararapira, em que se localizam ambas as comunidades Enseada da Baleia e Nova Enseada $^{6}$. Atualmente, estão presentes na Ilha, além destas, sete comunidades tradicionais caiçaras (Itacuruçá/Pererinha, Marujá, Vila Rápida, Pontal de Leste, Foles e Cambriú), bem como sítios isolados e uma comunidade indígena Guarani M'Bya, chamada Pakurity, que se estabeleceu na Ilha em 1992. Em 1962, a Ilha foi transformada em parque estadual, através do Decreto Estadual $n^{\circ}$ 40.319, de 03 de julho de 1962 (GOVERNO DO ESTADO DE SÃO PAULO, 1962), ou seja, uma área protegida que não permite a sustentabilidade do ser humano, por ser uma UC de proteção integral. De qualquer forma, o plano de manejo fase 02, vigente no PEIC, reconhece a permanência de ocupantes tradicionais e de atividades realizadas pela família como os serviços turísticos ofertados por elas (SÃO PAULO, 2001).

\footnotetext{
${ }^{6}$ Em agosto de 2018, ocorreu o rompimento do esporão arenoso, obrigando a realocação das comunidades da Enseada da Baleia e Vila Rápida, sendo que a primeira destas teve parte de sua história relatada. A comunidade da Vila Rápida realocou-se às pressas para duas áreas diferentes da Ilha do Cardoso, com alguma negociação com os órgãos competentes e com alguns parceiros.
} 
FIGURA 1 - MAPA DA ÁREA DE ESTUDO

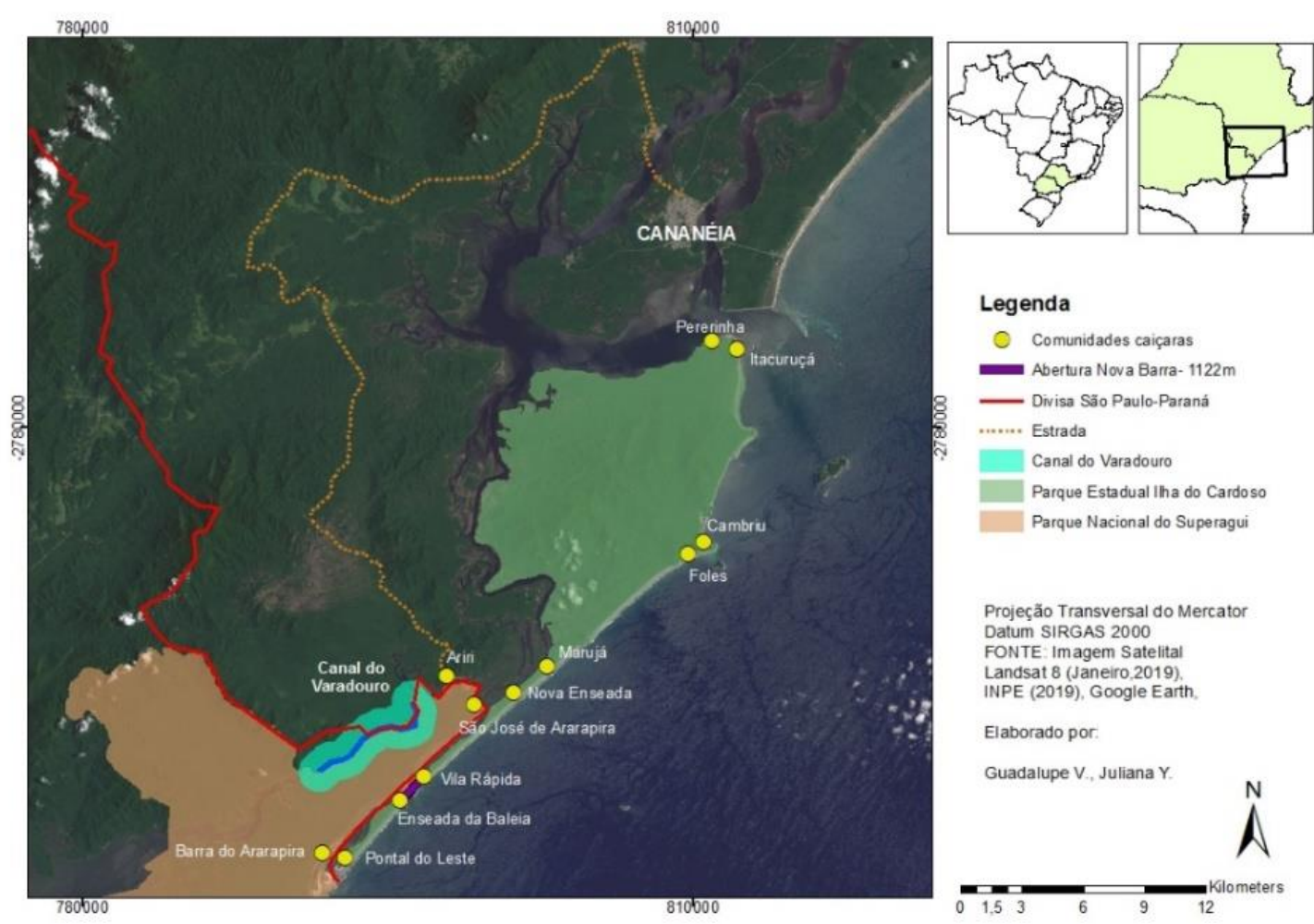

FONTE: Produzido por Vazquez e Yamaoka (2019).

A princípio contou-se com a aprovação da Comissão Técnico Científica (COTEC) do Instituto Florestal (IF), vinculados a Secretaria do Meio Ambiente (SMA) do Estado de São Paulo, que regula pesquisas em unidades de conservação estaduais. Além da aprovação da Associação de Moradores da Enseada da Baleia (AMEB) para a realização da pesquisa e metodologia, já que existe preocupação em relação ao retorno à comunidade dos dados trabalhados.

A coleta de dados primários combinou procedimentos metodológicos diversos, como: três grupos focais entre os meses de julho e dezembro de 2018 (com representantes da comunidade e alguns parceiros na Nova Enseada), observação participante, diário de campo, entrevistas semiestruturadas a partir de snowball, com base em Baldin e Munhoz (2011), com parceiros que não estiveram presentes nos encontros. Os grupos focais trataram de dados relacionados as atividades socioprodutivas femininas, resistência e realocação. Dada a complexidade do tema, as entrevistas semiestruturadas trataram basicamente destas vias de resistência. Os participantes das atividades assinaram Termos de Consentimento Livre e Esclarecido, totalizando 17 entrevistados, maiores de idade, participantes de grupos focais e entrevistas, que incluem famílias da Enseada da Baleia e parceiros da comunidade (do poder público, iniciativa privada e terceiro setor). 
Para a coleta de dados secundários, foram utilizados documentos do PEIC (plano de manejo, atas etc.) e documentos da comunidade da Enseada da Baleia e relacionados a ela (material audiovisual, matérias jornalísticas, material de comunicação, atas etc).

Para a fase final, em que se procede ao processamento dos dados, foram realizados alguns procedimentos de análise de conteúdo. Baseado nas vias de resistência e enfrentamento, propostas por Mafra (2018), que "analisou a ligação de resistências de pescadores artesanais na luta pelo território e as formas hegemônicas de produção do espaço ou apropriação dos recursos no litoral do Paraná", identificando como as resistências influenciam na territorialização e na produção socioespacial. Para isso, categorizou oito vias de resistência e enfrentamento, sendo elas: a) movimentos sociais e demais organizações coletivas; b) reconhecimento do território por meio de cartografias sociais, mapeamentos participativos e demais formas de levantamento de informações dos usos e costumes locais; c) ocupação de espaços púbicos e de áreas comuns de uso ou apenas permanecer no seu território; d) ações judicializadas, recomendações dos atores da justiça e acesso às demais instâncias judiciais; e) manifestações ou demais formas de mobilizações públicas; f) ações cotidianas de resistência e enfrentamento; g) acordos para uso do espaço e dos recursos e demais formas de negociação para melhoras nas condições dos pescadores artesanais; e h) manutenção, valoração e adaptação da tradição cultural como forma de resistência. Estas oito vias de resistência e enfrentamento serviram de base para a análise daquelas que se aplicavam ao caso da comunidade caiçara da Enseada da Baleia, onde se encontraram cinco das vias sugeridas, além da resistência cotidiana, proposta por Scott (2011) e igualmente incorporada ao estudo de Mafra (2018). Para tratar destas vias foram criados seis subitens, que compõem a quarta seção desse artigo.

\section{Resistência para a permanência na Ilha do Cardoso}

Resistir para permanecer na Ilha do Cardoso é parte do anseio daqueles que ficaram na Ilha, que não foram expulsos pelos diversos vetores de pressão que ocorreram durante seu processo histórico. Valle (2016) realizou sua pesquisa com representantes das comunidades tradicionais caiçaras do Marujá, Enseada e Itacuruçá/Pererinha, e traz elementos para refletir não apenas sobre a importância da permanência no território físico, mas em seu papel simbólico e construtor de identidades.

Perder o território, dessa maneira, significa desaparecer. Essa noção de território se reflete, por exemplo, nos caiçaras do PEIC. Para eles, a permanência no parque não se trata apenas de garantir o local onde moram, mas sobretudo garantir o local que 
representa tudo o que eles são e construíram ao longo do tempo (VALLE, 2016, p. 39).

Em se tratando do caso específico da Enseada da Baleia durante a pesquisa, algumas pessoas responderam apenas que ficar na Ilha é melhor (ENTREVISTADA 02). Mas para o Entrevistado 01, entre os motivos para a permanência na Ilha do Cardoso, estão a preservação da identidade e dos costumes que se tem quando se vive na Ilha,

Eu já saí e não me adaptei. [...] Hoje está sendo muito mais fácil que há alguns anos atrás. [...] O vínculo está aqui. Quando se mora na cidade, você não vê ninguém mais. Mesmo morando há umas quadras da sua irmã ou de qualquer outro, não encontra. Acabou comunidade, acabou tradicional, acabou o caiçara, acabou tudo se sair fora daqui. Tudo se mantém porque a gente mora em uma comunidade na Ilha do Cardoso, por isso tem que resgatar e manter isso. Se sair fora daqui perde tudo isso (ENTREVISTADO 01).

Historicamente, a Igreja Católica através do Padre João Trinta, foi um dos apoiadores mais lembrados na resistência às pressões que recaíram sobre a Enseada no passado. Segundo o Entrevistado 01 “[...] acho que estamos onde estamos porque aprendemos muito com ele, Pe. João. [...] Tudo que a gente faz hoje tem a ver com aquela época". Fala-se que para além da questão religiosa, “[...] ele olhava para a necessidade das comunidades também, né. Ele ajudava, em todas as comunidades tinha ajuda dele" (ENTREVISTADA 01). Ele teve um papel importante na formação das pessoas que resistem, hoje em dia e na formação de lideranças em todo município de Cananéia. "E a gente ia muito para encontros, né. Então aprendemos a falar, a perder a vergonha" (ENTREVISTADA 03). Com o falecimento dele no ano de 2008, fica na comunidade a preocupação de que não teriam para quem pedir ajuda.

O processo de resistência na comunidade da Enseada, tem várias faces. Mesmo que houvesse interesse pela realocação, já que a comunidade vinha vivendo com insegurança desde a intensificação do processo erosivo (a partir de outubro de 2016), vivenciar a realocação é um processo intenso e não homogêneo entre as pessoas envolvidas. Suas famílias tinham acabado de superar uma crise profunda, com o falecimento do Sr. Malaquias (o patriarca da família), em 2010 e tinham a sensação de que estariam num momento de estabilidade financeira na antiga vila da Enseada da Baleia. Optar pela realocação em um local em que precisariam construir tudo novamente, era algo complexo, custoso e que exigiu muito trabalho. Não se tratava apenas de reconstruir residências, mas de reencontrar pontos de água potável e cuidar de toda estrutura básica, de reorganização das atividades produtivas em um local que era de mata fechada e que ainda não conheciam tão bem. Esses eram fatores de insegurança para a comunidade, mesmo tendo optado por uma localidade que oferecesse condições de seguir com suas práticas, que estão detalhadas no item 4.2. 


\section{Ações judicializadas}

Para Mafra (2018, p. 70) a via de resistência correspondente à ações judicializadas, refere-se à “[...] presença de processos judiciais individuais ou coletivos pelo controle do território (dados dos processos, grupos envolvidos, tipos de ação, datas principais, quem ajuizou a causa, histórico do processo, ganhos e perdas)". Neste caso existe uma ação judicial, com características coletivas, que opera em favor da territorialização da comunidade caiçara.

Um acidente ocorrido em fevereiro de 2015, que destruiu cinco construções na comunidade da Enseada da Baleia, impulsionou a busca da comunidade pela Defensoria Pública do Estado de São Paulo (DEPESP). Como resultado da parceria, o Procedimento Administrativo de Tutela Coletiva 07/15 foi instaurado no mesmo ano com a finalidade de assegurar a permanência da comunidade na Ilha do Cardoso (caso fossem realocados) e apurar a responsabilidade da instituição que era proprietária da embarcação, que gerou o desastre socioambiental na Enseada da Baleia. Não havendo acordo com a parte, foi instituída uma Ação Civil Pública ${ }^{7}$ (HAYAMA; CARDOSO, 2018). A Associação de Moradores da Enseada da Baleia (AMEB) judicializou uma única vez, em função da ausência de acordo com a instituição responsável pela embarcação turística que causou o acidente . $^{8}$

Diante desse contexto, fica demonstrada a importância destes atores, Defensorias Públicas ${ }^{9}$, por proporcionarem acesso à justiça àqueles que anteriormente não teriam por ausência de capital ou poder. Antes dessas instituições, a justiça estava restrita àqueles que podiam pagar advogados. A partir destas, foram viabilizados novos arranjos que podem garantir direitos territoriais às comunidades tradicionais.

\section{Reconhecimento do território por meio de mapeamentos participativos}

As cartografias sociais e mapeamentos participativos podem ser uma outra via de resistência, “[...] automapeamentos e demais ações de valoração e reconhecimento de identidade (características gerais, resultados, grupos envolvidos)" (MAFRA, 2018, p. 70). Mas não há consenso sobre este uso, Acselrad (2008, p. 9) considera que no debate contemporânea a respeito de cartografias sociais e

\footnotetext{
7 A ação civil pública em questão, da Defensoria Pública do Estado de São Paulo, está disponível através do https://racismoambiental.net.br/wp-content/uploads/2016/12/ACP-ENSEADA-DA-BALEIA.pdf.

${ }^{8}$ Além desta, existem diversos processos administrativos em órgãos públicos como: Fundação para a Conservação e Produção Florestal do Estado de São Paulo (FF), Companhia Ambiental do Estado de São Paulo (CETESB), Instituto Brasileiro do Meio Ambiente e dos Recursos Naturais Renováveis (IBAMA), Ministério Público Federal (MPF) e Ministério Público do Estado de São Paulo (MPE-SP). Os processos administrativos têm potencial para se transformarem em processos judiciais, o que não ocorreu até o momento.

${ }^{9}$ Sobre a atuação da Defensoria Pública em especial, Santos (2016) afirma que ela incorporou diversos aspectos do tipo ideal inovador de serviços legal. Mas salienta que apesar de ter competência legal para lidar com interesses difusos e coletivos, como para o ingresso em Ações Civis Públicas (ACP), não é uma instituição homogênea. A Defensoria teria mais condições institucionais e legais para dar conta de um país com enorme dificuldade de acesso à Justiça.
} 
mapeamentos participativos podem "[...] ser vistas como esforços de resistência às dinâmicas de globalização, ora como instrumento de apoio à efetivação mesma destas dinâmicas”.

Para a discussão do reconhecimento do território, faz-se necessário lembrar que este caso está posto em territórios tradicionalmente ocupados. A participação dos moradores tradicionais na elaboração do Plano de Manejo do Parque Estadual da Ilha do Cardoso ${ }^{10}$ foi fundamental para a garantir seus direitos de permanência na Ilha, bem como, reconhecer suas atividades de visitação pública, roçados e extrativismo (VALLE, 2016). Além disso, um laudo antropológico atesta a tradicionalidade das famílias, realizado em 2012.

Sobre o etnomapeamento realizado junto à comunidade no final de 2016, a comunidade contou com o apoio do Núcleo de Apoio à Pesquisa sobre Populações Humanas e Áreas Úmidas Brasileiras (NUPAUB) ligado a Pró Reitoria de Pesquisas da Universidade de São Paulo (USP) ${ }^{11}$ para a realização de um trabalho de etnomapeamento do território da Enseada da Baleia e do que viria a tornar-se a Nova Enseada. Quando realizado, a localidade era reconhecida como sítio Casa Preta, "[...] situado a 7 metros do nível do mar, lugar de antigo sítio de assentamento. Existem evidências materiais de antigas construções, além de valas e poços que abasteceram a residência" (NUPAUB, 2016, p. 73) e a área da prainha, que está localizado há aproximadamente 500 metros da primeira. Sobre a indicação da nova localidade, o relatório inclui carta elaborada coletivamente:

A Comunidade da Enseada da Baleia se reúne no dia treze de novembro de dois mil e dezesseis. Comparecem ao encontro toda a comunidade, representada pela Associação de Moradores da Enseada da Baleia, AMEB, para tratar do assunto da realocação, onde foram levantadas quais são as atividades e as necessidades da Comunidade. Foram levantadas os benefícios da área da Casa Preta: Atividade pesca do irico e outras espécies; Árvores grandes; A vó já morou na área (Erci Malaquias); Espaço grande; Segura; Diversidade Ambiental (ajudaria no turismo comunitário); Facilidade de acesso; Lancha (DERSA) diariamente; Economia de recurso; Atividade da área da Tumba (RESEX); Mais alternativas de renda. Foi levantada pela Comunidade a necessidade de usar a área da Prainha (lado direito) da Casa Preta para complementação das atividades da vida diária da Enseada da Baleia, comparando ao que acontece hoje: Ponto de pesca; Turismo; Praia de acesso ao estuário; Laser (campo de futebol e vôlei). (NUPAUB, 2016, p. 71-72).

\footnotetext{
${ }^{10}$ No Plano de Manejo do PEIC, foram reconhecidos como moradores tradicionais àqueles que apresentassem às "seguintes características: o chefe da família, deve estar há, no mínimo, 3 gerações na Ilha do Cardoso; ii) desenvolvem atividades de baixa interferência no meio ambiente: pequena escala e baseada no uso dos recursos renováveis; e iii) tem conhecimento e domínio das técnicas tradicionais (pesca, agricultura e construção)" (GOVERNO DO ESTADO DE SÃO PAULO, 2001).

${ }^{11}$ Para a realização de atividades de etnomapeamento, “[...] eixo em torno do qual se estruturaram as atividades dialógicas, transcenderam o simples registro cartográfico nativo, sintetizando este processo de construção coletiva da proposta de reassentamento, que evidencia a importância dos marcos identitários impressos no território - seu lugar antropológico permitindo a expressão plena da subjetividade local, condição necessária para atender plenamente as perspectivas autodeclaratórias apontadas na Convenção 169 da OIT” (NUPAUB, 2016, p. 16).
} 
O processo foi feito coletivamente, através de desenhos em flip chart, que possibilitou o levantamento das famílias, áreas de uso da antiga comunidade e a nova área, e como seriam as atividades socioprodutivas. Os homens tinham uma visão do território em que conseguiam diferenciar áreas altas e baixas, o que foi importante para conseguirem encontrar a nova área, já que existem áreas que alagam na restinga. Quando chegaram, com a mata fechada, cada família foi procurando local para as residências e batendo coordenadas, eles mesmos. Assim, montou-se um mapa. Além da segurança, a decisão se deu com uma indicação da avó, que já tinha residido ali e sabia da existência de água potável e das árvores frutíferas. Os pescadores, já conheciam porque lanceavam por vezes próximos a localidade, e sabiam que seria o último ponto para a pesca do iriko ${ }^{12}$.

Acselrad e Coli (2008), afirmam que as iniciativas de inclusão de populações locais em mapeamentos disseminaram-se mundialmente, na década de 1990. No caso do etnomapeamento, o prefixo "etno" é atribuído a um grupo étnico, descrito por Little (2006, p. 16-17), como “[...] uma coletividade de indivíduos que se diferencia dos demais grupos por sua especificidade sociocultural". No etnomapeamento, identificam-se dois tipos básicos de mapas: os mapas mentais e os mapas georreferenciados (com técnicas cartográficas ocidentais), sendo que existe certa pressão por parte dos financiadores para se chegar no segundo tipo, o que chama de "fetichismo dos mapas" (LITTLE, 2006, p. 30). A importância do território se dá por funcionar como base material da identidade étnica, como o conjunto do espaço geográfico, suas relações históricas, vínculos mitológicos, subjetividade. " $\mathrm{Na}$ medida que os grupos étnicos levantam reivindicações frente ao Estado, se transformam em movimentos etnopolíticos" (LITTLE, 2006, p.17).

A realização do etnomapeamento facilitou a escolha da nova área pela comunidade e a reflexão sobre as áreas de uso, através da combinação de ferramentas. Muito da negociação dependia da decisão da nova localidade por parte da comunidade, e isso se deu com este trabalho. Apesar de ele não ter sido usado no processo administrativo, embasou outros documentos que foram fundamentais na negociação e licenciamento da área. Os documentos foram processados por técnicos externos à comunidade, mas isso não significou problema para as famílias envolvidas, por estarem sobrecarregadas de funções no período.

\footnotetext{
${ }^{12}$ A Instrução Normativa $\mathrm{n}^{\circ}$ 15, de 16 de junho de 2005 (MMA, 2005), que estabelece normas, critérios e padrões para a pesca de juvenis das espécies Anchoa marinii, Anchoa tricolor, Anchoa lyolepsis, conhecidas popularmente como "manjuba ou iriko", e determina em seu art. $1^{\circ}$ - Permitir o exercício da pesca do iriko no canal da Ararapira entorno do PEIC, no Estado de São Paulo e na zona de amortecimento do Parque Nacional de Superagui no Estado do Paraná, somente na área compreendida a 1.000 metros da barra do Ararapira até 1.500 metros a norte da desembocadura do canal do Varadouro.
} 


\section{Negociações com atores contrários}

Outra via para a compreensão de processos de resistência, seria a leitura de como se deram as negociações com atores contrários. Como negociações entende-se “[...] negociações com atores contrários (grupos envolvidos, resultados, origem da negociação)” (MAFRA, 2018, p. 70).

Recentemente, não se tem notícias de atores que se posicionaram contra o processo de realocação da comunidade da Enseada da Baleia, mas os depoimentos e arquivos históricos, demonstram que houve negativas ou dificuldades ao longo da negociação. Por se tratar da realocação de uma comunidade tradicional dentro de uma área de unidade de conservação (UC) de proteção integral. Percebem-se diferentes posicionamentos, entre elas, instituições que tem condutas mais próximas da legislação ambiental e menos aceitabilidade da legislação que reconhece os direitos de povos e comunidades tradicionais, o que propiciou que toda a negociação fosse realizada com cautela. Em conversa na comunidade da Nova Enseada em 2018, Diegues fala que este é o único caso conhecido de realocação para UC dentro de tal categoria, com aval no Estado de São Paulo. Tal fato demonstra que são raros os casos em que este tipo de negociação finda com resultado positivo para a comunidade.

Uma matéria jornalística $^{13}$, de 2011 , demonstra que havia clareza em relação a necessidade de realocação da comunidade e que isto estava certo, mas questiona se haveria "verbas" para situações emergenciais como esta. Anos mais tarde, fica evidente que houve o licenciamento para uma nova área, mas ficou a cargo da comunidade a mobilização de recursos para que conseguissem fazer esta realocação em curto espaço de tempo o que inviabilizaria a ação, caso não estivesse organizada. Meses mais tarde, ainda em 2011, um parecer da assessoria jurídica da Secretaria do Meio Ambiente (SMA) foi lido na reunião do Conselho Consultivo do PEIC ${ }^{14}$, negando-lhe a permanência na ilha, por se tratar de uma unidade de conservação de proteção integral (PARQUE ESTADUAL DA ILHA DO CARDOSO, 2011).

Enquanto as negociações mais difíceis aconteceram fora da comunidade, dentro dela as negociações da comunidade da Enseada da Baleia se deram no sentido de sensibilizar pessoas, de diferentes instituições, buscando parceiros que pudessem apoiá-los em diferentes espaços de decisão. Dificuldades de negociação foram indicadas, principalmente com o MPE-SP e a SMA de São Paulo. Sobre a primeira instituição, o Depoente $1(2016)^{15}$ fala em entrevista ocorrida no ano em que se negociava o licenciamento para a nova área, que “[...] a situação é bastante insegura, inclusive os

\footnotetext{
13 Série Comunidade Caiçara / Prog. 3 - Enseada da Baleia / Bloco 2, publicado em 31 de janeiro de 2011.

${ }^{14}$ O Conselho Consultivo do Parque Estadual da Ilha do Cardoso foi formado com o nome de Comitê de Apoio a Gestão do PEIC, em 1998 e tem uma longa trajetória de negociação entre comunidades tradicionais, sociedade civil organizada e gestão pública para a busca de caminhos de parceria, o que é descrito por Campolim, Parada e Yamaoka (2008).

${ }^{15}$ Depoimento extraído de material audiovisual dos arquivos da comunidade, de entrevista realizada no ano de 2016.
} 
órgãos ambientais, incluindo nisso o MPE-SP, vem resistindo a ideia da comunidade optar por uma outra área dentro na Ilha do Cardoso, caso este risco se torne insuportável”.

Sobre a segunda instituição, segundo o Entrevistado 12 era um período em que a Fundação Florestal gerava a documentação e a discussão, mas levava os assuntos para uma decisão superior, no caso da SMA. A reunião que decidiu sobre a possibilidade de licenciamento da área da Nova Enseada foi marcada com a ajuda de órgãos de justiça, DEPESP e MPF.

No mesmo período, a SMA estava encaminhando uma outra agenda, que ocorre pouco depois da negociação que é referente a aprovação da Lei Estadual no 16.260, de 29 de junho de 2016 (SÃO PAULO, 2016). Tal lei aparece como uma preocupação presente na Comunidade da Enseada da Baleia e representantes de outras comunidades da Ilha do Cardoso. A política de concessão de unidades de conservação, incluiu em sua estrutura uma lista de 25 unidades de conservação, sendo que o PEIC é uma delas (SÃO PAULO, 2016). Em todas as comunidades tradicionais caiçaras da Ilha do Cardoso, existem atividades turísticas, atualmente. A legislação vem sendo debatida, por sua rapidez e negligência em relação a participação das comunidades.

Compreender por que uma negociação de supressão da vegetação de uma localidade para a realocação de uma comunidade em risco é difícil e, por outro lado, se tem prioridade em uma agenda de concessão à iniciativa privada das atividades turísticas e a exploração da madeira nas Unidades de Conservação é um caso para reflexão. Esse contexto remonta a discussão proposta por Diegues (2001), das diferentes linhas de ecologismos, em que apresenta uma modalidade, o "ecologismo camponês", que vinha sendo trabalhado por alguns autores e que teria surgido entre movimentos sociais do "Terceiro Mundo", compreendendo a crise ambiental e miséria crescente como resultados dos atuais modelos de desenvolvimento. Este novo ecologismo, é aprofundado e trabalhado por Alier (2007) que dividirá em três correntes principais de ecologismos. Como "culto a vida silvestre", entende-se a corrente de defesa da natureza intocada, que terá como estopim o amor às paisagens. Uma segunda corrente que chamou de "evangelho da ecoeficiência" acredita no desenvolvimento sustentável, na modernização ecológica, na boa utilização dos recursos, capital natural e serviços ambientais. Alerta sobre como ambos convivem atualmente, simultaneamente. E, finaliza com a terceira corrente, que seria a da "justiça ambiental e o ecologismo dos pobres", que desafiaria as primeiras duas e que também é reconhecida por ecologismo popular ou movimento de justiça ambiental. Esta corrente, chamaria atenção para o deslocamento geográfico de recursos, denunciando as extrações de petróleo, gás, alumínio, cobre, eucalipto, ouro, soja transgênica, que avançam sobre novos territórios e grupos sociais que por vezes, protestam e resistem. 
Evidenciando que órgãos ambientais como a SMA tem uma agenda política com marcadas expressões das correntes do "culto a vida silvestre" e do "evangelho da ecoeficiência", que ainda mantém marginalizados os encaminhamentos junto a povos e comunidades tradicionais e que priorizam respostas às demandas de mercado. O que fez com que uma quantidade de esforço e articulação maior fosse organizada para prosseguir com o processo de realocação da comunidade da Enseada.

\section{Movimentos sociais e demais organizações coletivas}

A quarta via de resistência identificada, é aquela que se propõe a descrever atores locais e "movimentos sociais, colônias, associações de moradores e pescadores, instituições de pesquisa e extensão, instituições ligadas à justiça local, instituições ambientais locais e demais atores ligados à territorialização dos pescadores" (MAFRA, 2018, p. 70). Além disso, observa-se a ligação destes atores com as ações de luta pelo território.

A comunidade tem uma associação que a representa, a AMEB, fundada em novembro de 2015, na qual desde o início os principais cargos da diretoria são compostos por mulheres. Mas a organização comunitária é anterior à data, e 2015 seria apenas o ano de sua formalização. A demanda pela formalização já ocorria em função do Conselho Consultivo do PEIC, mas foi depois do acidente de fevereiro de 2015 que o grupo foi aconselhado pela DEPESP a se formalizar para a ação, e assim o fizeram. A AMEB não é tida como a responsável pela permanência deles na Ilha, mas como "ferramenta" necessária para que trabalhem juntos. A união e os mutirões são lembrados como determinantes neste processo.

De qualquer forma, a articulação necessária para que obtivessem o licenciamento da nova área e depois, para que conseguissem realocar-se num curto espaço de tempo, não seria possível se não houvesse o envolvimento de muitos outros atores externos. Portanto, a partir das entrevistas e documentos organizou-se uma listagem daqueles que apoiaram a comunidade, em diferentes momentos tanto nos depoimentos de comunitários quanto parceiros (GRÁFICO 1). 


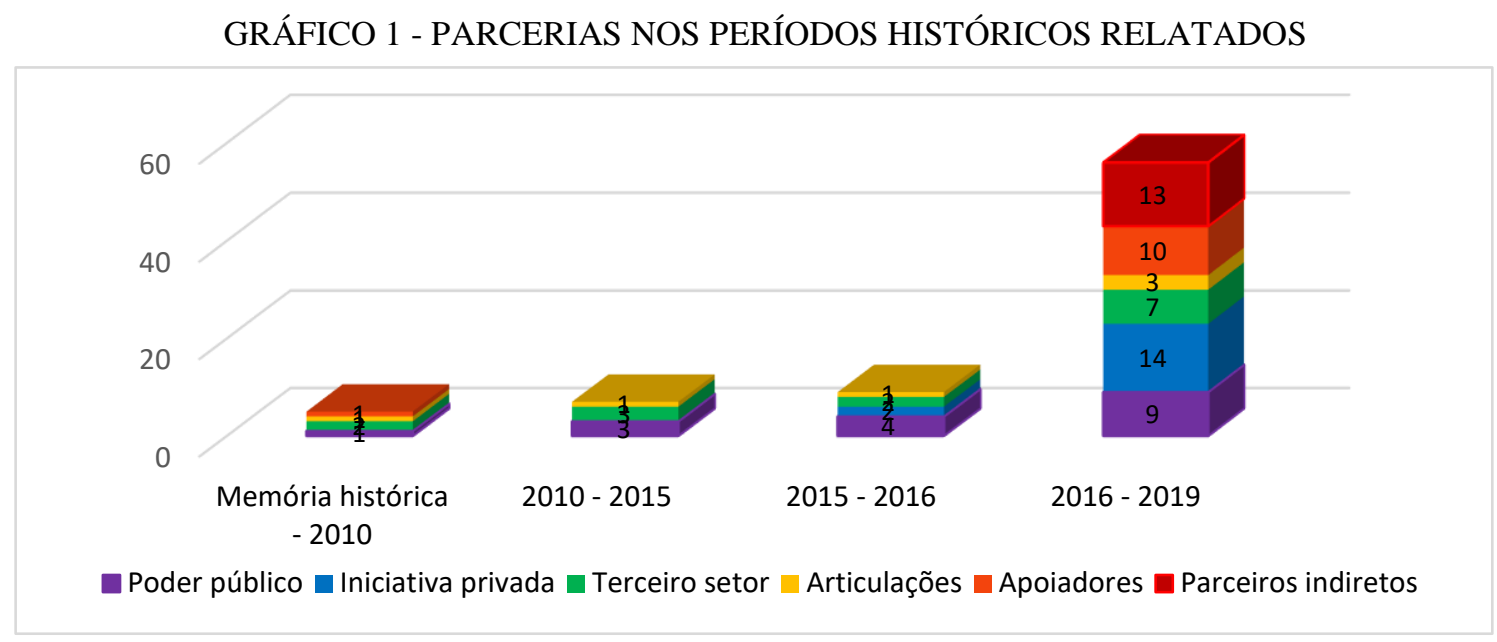

FONTE: Elaboração própria (2019).

O GRÁFICO 1 reúne informações de parcerias que foram mapeadas a partir das entrevistas, grupos focais e documentos. Além disso, buscou-se separar em quatro tempos históricos que estão presentes nas falas: i) memória histórica - 2010: um tempo mais antigo que ainda consta na memória dos entrevistados e que foi até o falecimento do Sr. Malaquias em 2010; ii) 2010 - 2015: entre o falecimento de Sr. Malaquias e o acidente ocorrido na comunidade em fev.2015; iii) 2015 - 2016 : depois do acidente com embarcação turística e a intensificação do processo erosivo que ocorre em outubro de 2016, quando se evidencia a necessidade da realocação imediata; iv) 2016 - 2019: o último momento, que corresponde a intensificação do processo erosivo, a realocação da comunidade para a Nova Enseada. Adotou-se como critério o início do trabalho em parceria, já que muitos mantiveram seus apoios em períodos sequentes. Com o volume de informações, separou-se os apoiadores em seis grupos: a) $1^{\mathrm{o}}$ setor (poder público), b) $2^{\circ}$ setor (iniciativa privada), c) $3^{\circ}$ setor (sociedade civil organizada), d) articulações (redes, conselhos e movimentos sociais), e) parceiros indiretos (grupos de pessoas ou organizações que atuaram nas campanhas de apoio da comunidade sem conhecer a causa em profundidade, chamados por pessoas que tem afinidade com a comunidade), e f) apoiadores (categorias de profissionais ou representações que apoiaram determinada situação sem a especificação de quais são estas pessoas físicas ou coletivos, exemplos desse são mobilizadores de recursos, comunicadores, comunidades tradicionais etc). Este último grupo, inviabilizaria a quantificação exata de cada período. De qualquer modo, verifica-se uma ampliação na rede de articulação ao longo do tempo, que pode estar ligada a complexidade de cada período e as dificuldades que a comunidade teve no último período descrito com o processo de realocação. 
Um fator a ser considerado é a participação em movimentos sociais. Inicialmente, os encontros relatados eram promovidos pela igreja católica ${ }^{16}$. Anos mais tarde, em 2010 e 2011, começam a participar de encontros junto ao movimento social da Economia Solidária Feminista, encontros de Pescadores Artesanais (2014) e por fim, de povos e comunidades tradicionais (2015), e dos caiçaras ${ }^{17}$ (2016). Estas participações criaram oportunidades de reconhecimento de experiências diversas em comunidades tradicionais ou coletivos de base, em que a resistência é estimulada pela troca de experiências e vivências. Os intercâmbios viabilizados por parceiros tinham foco nas mulheres ou contavam com suas representações. Os homens tiveram a oportunidade de visitar uma produção de mariscos (2014) e de saneamento rural (2018) através de projetos comunitários propostos pela Associação. Novas habilidades foram geradas, quando participavam dos encontros da Igreja, mas não se entendia quais eram as organizações que estavam apoiando o grupo, e nem eram eles quem propunham os projetos comunitários. Ao relatar sobre a participação em movimentos sociais, agora são as mulheres da comunidade quem procuram parceiros e que escrevem os projetos, através da AMEB.

Para Gohn (2011), há produção de saberes e aprendizagens em outros espaços que não sejam a educação escolar, o que ela chama de educação não-formal. Um dos exemplos seria a partir de movimentos sociais e ações coletivas, em que há um caráter educativo nestas práticas, quando ocorrem diálogos, confrontos e negociações. Mesmo com uma produção teórica pouco expressiva sobre o assunto até o começo do século XXI, no Brasil, os movimentos sociais são formas da população se organizar e expressar demandas, através de ações sociais coletivas com caráter sociopolítico e cultural. Eles expressam resistência ao que os oprimem ou trabalham na construção do novo que os liberta. Realizam diagnósticos sobre a realidade social, constroem propostas, atuam em redes, agem como resistência à medida que constroem ações coletivas e lutam por inclusão social $^{18}$.

\footnotetext{
${ }^{16}$ Os entrevistados não souberam definir a qual movimento social estariam atrelados neste momento, se referindo apenas ao representante da igreja católica localmente que seria o contato para este tipo de encontro.

${ }^{17}$ Segundo o Depoente 2 (2016), a Coordenação Nacional das Comunidades Tradicionais Caiçaras (CNCTC), criada em 2014 é resultado da participação de caiçaras na Comissão Nacional de Desenvolvimento Sustentável de Povos e Comunidades Tradicionais (instituído pelo Decreto de 13 de julho de 2006 e revogado através do Decreto 9.759, de 11 de abril de 2019), que tinha sido transformado em Conselho Nacional dos Povos e Comunidades (através do Decreto 8.750 de 09 de maio de 2016) e da inspiração na Coordenação das Comunidades Negras Rurais Quilombolas (CONAQ). Este depoimento foi extraído dos arquivos audiovisuais da comunidade da Enseada da Baleia. Segundo Almeida (2008), que fala sobre as inúmeras reivindicações para a consolidação das territorialidades de comunidades caiçaras do litoral de São Paulo, junto ao MPF, este se caracterizaria como um "novo movimento social” de acordo com Hobsbawn (1995), caso estas existências atomizadas passassem a uma mobilização continuada.

${ }^{18}$ Considerando-se que neste caso, trata-se de um estudo com representantes de comunidades tradicionais, a inclusão social, poderia ser substituída pela noção de redistribuição e reconhecimento, abordados por Fraser (2006), que contextualiza a possível simultaneidade de duas "problemáticas atualmente dissociadas" no contexto estadunidense e europeu e retrabalhados por Cruz (2013, p. 40), para o contexto de lutas territoriais latino americanas e especialmente brasileiras, em que se tem duas lógicas, que podem estar "articuladas e enredadas", como a "redistribuição material da
} 
No caso da Comunidade da Enseada da Baleia, suas vivências e a articulação com movimentos sociais e instituições parceiras, propiciaram o desenvolvimento de novas habilidades que foram muito importantes no processo estratégico da resistência, articulação e negociação com atores participantes. Sendo que, o sistema formal de ensino seria insuficiente para o desenvolvimento de tais habilidades mais propositivas para momentos de crise, como o que foi vivido ao longo do período relatado, que vai de 2010 até o momento atual. Além disso, verifica-se que a solidariedade também se constrói com a resistência, com a luta e com os conflitos que se renovam com o passar do tempo, além da empatia que estes processos geram, dando abertura para o apoio às comunidades próximas.

\section{Manifestações ou demais formas de mobilizações públicas}

Uma outra questão que ajuda a compreender como se deu o processo de resistência dos caiçaras da Enseada da Baleia é a análise de manifestações e outras formas de mobilização pública. Segundo Mafra (2018, p. 70) entende-se pela categoria de resistência proposta, a "presença de mobilizações ocupações, abaixo-assinados, denúncias na imprensa, atos públicos e demais atividades coletivas (grupos envolvidos, principais motivos, resultados alcançados)".

O processo de mobilizações públicas se inicia mais fortemente depois de obtida a licença para a realocação da comunidade. As casas das famílias caiçaras geralmente são construídas ao longo de suas vidas, melhorando ou ampliando à medida que existem melhores condições para a realização de tais investimentos. O NUPAUB (2016) descreveu as casas da Enseada da Baleia como àquelas que seguiam o padrão da região: estrutura de madeira assentada em concreto, o piso geralmente de cimento "queimado", a cobertura de "telhão", cozinhas e banheiros, em alvenaria. Para viabilizar a reconstrução de casas e espaços comuns na Nova Enseada, em curto espaço de tempo, foram organizados ao menos oito eventos/campanhas públicas de mobilização de fundos. Desses, um foi realizado pela internet e sete foram realizadas presencialmente, entre exposição de fotos e festivais de música. Todos contaram com o apoio de parceiros.

A Campanha “Ajude a Nova Enseada” se iniciou através de uma fanpage no Facebook ${ }^{19}$, com pedidos de depósito de doações na conta da AMEB. Vinculada a esta Campanha foi realizado um financiamento coletivo através da plataforma Benfeitoria, em dezembro de 2016, que teve como meta arrecadar R\$ 15.000,00 para o financiamento de moradias, sendo que dentro desta meta seria “[...] viabilizada a moradia da Dona Erci, matriarca da família" (BENFEITORIA, 2016), no prazo de 60 dias e que teve êxito.

\footnotetext{
riqueza e das condições materiais de uma sociedade;" além do "reconhecimento das diferenças e do direito à diferença", que resultaria em mudança política e cultural dos valores.

${ }^{19}$ A campanha “Ajude a Nova Enseada” está disponível em: https://www.facebook.com/ajudeanovaenseada/.
} 
O financiamento coletivo ou crowdfunding é uma ferramenta de captação de recursos que vem ganhando espaço atualmente. Se faz através do ambiente virtual da internet, com a finalidade de angariar apoiadores para causas diversas e depende de um site especializado para a divulgação desta ideia, a definição de uma causa, custos, um vídeo explicativo e o pedido de apoio e recompensas para quem apoiar. Caso não se consiga cumprir com a arrecadação dentro do período, o valor é devolvido. Se atingirem a meta, devem cumprir com as "recompensas" prometidas, sendo que quanto maior o valor, maior a recompensa (SILVA et al., 2014).

Para a realização dos sete eventos presenciais, houve similaridades: contaram com a proposição de amigos ou instituições parceiras, foram realizados nos locais em que estes tinham acesso, e seis deles contaram com o apoio ou participação direta das famílias da Enseada. Entre dezembro de 2016 e outubro de 2017 ocorreram: festivais de música ( $1^{\circ}$ e $2^{\circ}$ Atos em Solidariedade à Enseada da Baleia e Forró de Amigos da Enseada) em São Paulo - SP e Ilha Comprida - SP, exposição fotográfica (Estreitos: retratos da Ilha) em Ribeirão Preto - SP, festas comunitárias ( $3^{\mathrm{a}}$ edição da Festa da Cataia e o Arraiá Caiçara) na comunidade do Pererinha (Ilha do Cardoso) e jantar (Jantar Dançante em prol à Comunidade Enseada da Baleia) em Cananéia - SP.

Este esforço é atribuído a relação próxima com a comunidade (ENTREVISTADO 15) e pelas relações afetivas (ENTREVISTADO 14). As ações acabaram envolvendo pessoas que ajudaram de alguma forma, mas que não sabiam o que se passava na Ilha do Cardoso e nem conheciam o local (ENTREVISTADO 13). Estes últimos, estão no GRÁFICO 1, como parceiros indiretos.

Além dos eventos outras formas de mobilizações públicas ocorreram. Entre as que merecem destaque estão as matérias jornalísticas. Entre 2011 e 2019, foram identificadas 87 matérias jornalísticas em meios de comunicação diversos (GRÁFICO 2), das quais duas são documentários. Elas foram separadas entre as notícias veiculadas através da Rede Cananéia ${ }^{20}$, organização em que a comunidade esteve como membro até 2018 e outras mídias (que variam da produção de documentários autorais a mídias de massa).

\footnotetext{
${ }^{20}$ As notícias da Associação Rede Cananéia foram veiculadas através de informativo impresso e através da página www.redecananeia.org.br.
} 


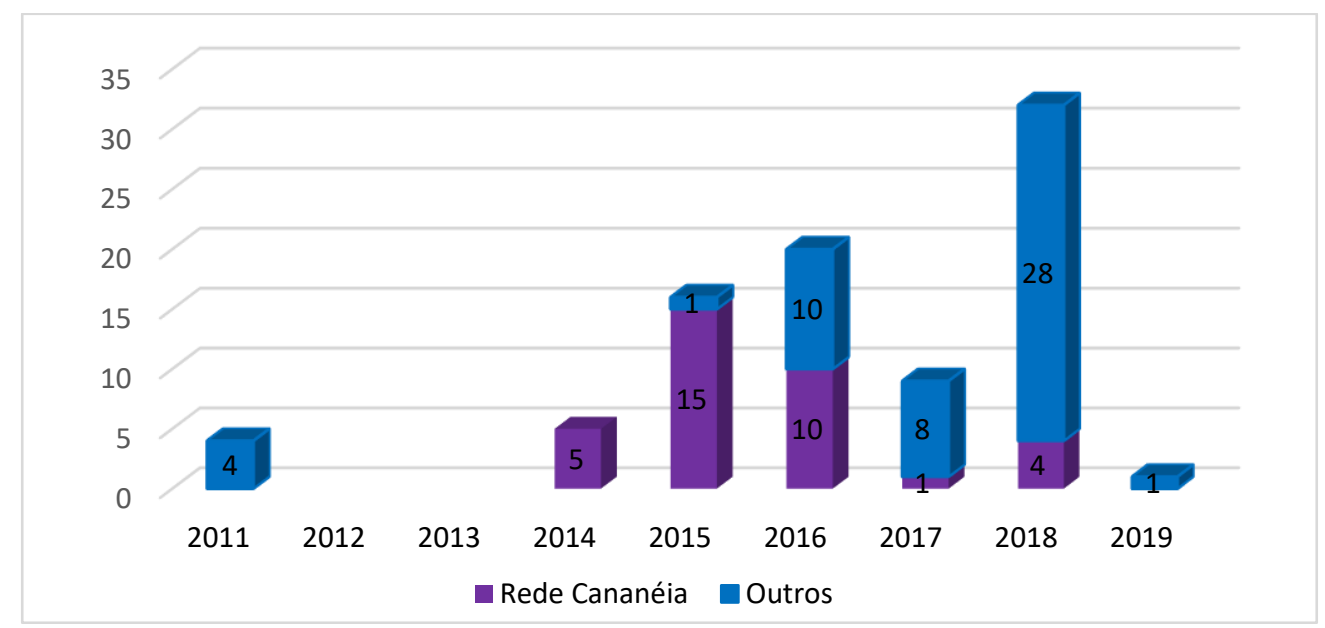

FONTE: Elaboração própria (2019).

Percebe-se pelo GRÁFICO 2 um aumento expressivo de matérias a partir de 2015, com matérias principalmente da Rede Cananéia; em 2016, o aumento também se dá em mídias diversificadas, com temas que variam entre: atividades produtivas femininas (a partir de 2014), o acidente de 2015, a necessidade de realocação que a comunidade da Enseada (em 2017), a abertura da barra (em 2018) e mudanças climáticas (a partir de 2018). A maioria das matérias contou com a participação efetiva das mulheres da comunidade, seja como entrevistadas ou organizadoras do receptivo e logística.

As mulheres da comunidade também foram responsáveis por outras atividades que influíram na resistência, como as tentativas diversas de captação de recursos através de editais e parceiros, com a finalidade de garantir o custeio da realocação das famílias da Enseada da Baleia. Estas tentativas não foram objeto da pesquisa, mas se deram pela habilidade do grupo para lidar com documentação e burocracias necessárias, além da facilidade para gerar material de comunicação para subsidiar estas várias frentes de ações criadas.

Decorrente dos esforços ligados a esta via de resistência, foram realizados oito eventos e campanhas com a finalidade de mobilizar recursos, responsáveis pela mobilização de aproximadamente 10 a $20 \%$ do montante necessário a construção da Nova Enseada. Foram realizadas, no total, oitenta e sete matérias jornalísticas sobre o tema da realocação da comunidade e/ou rompimento do esporão arenoso e impactos desta transformação da paisagem. Apesar desta produção significativa, não foi possível avaliar os impactos deste material nesta pesquisa, sendo uma possibilidade de futuras investigações. 


\section{Resistências cotidianas}

Mafra (2018, p. 70) tem como proposta verificar a "[...] presença de resistência cotidiana através da tradição e valoração da cultura (grupos envolvidos, principais motivos, resultados alcançados)". Esta via foi proposta por Scott (2011, p. 219), que chamou de formas cotidianas de resistência camponesa, que remete a luta entre estes camponeses e quem busca extrair-lhe trabalho, impostos, rendas, alimentos e juros. As caracterizando como aquelas que teriam pouca ou nenhuma coordenação, formas de autoajuda individual e que buscariam evitar confrontações com estes que lhes pressionam.

É evidente que o cotidiano da comunidade é repleto de manifestações relacionadas a tal via. As atividades socioprodutivas desenvolvidas pela Enseada trazem exemplos: a) pesca artesanal - em que existem desafios no processo de reterritorialização das artes de pesca artesanal na Nova Enseada; b) turismo comunitário - em que apesar do PEIC ser reconhecido como um caso de sucesso, existe a possibilidade de concessão das atividades turísticas através da Lei nº 16.260, de 29 de junho de 2016 (SÃO PAULO, 2016), que pode influenciar negativamente as comunidades que têm no turismo uma das atividades geradoras de renda; c) beneficiamento de pescado - tem desafios para a sua formalização devido à legislação; d) cultivo de hortaliças e plantas medicinais - as autorizações para roçado na Ilha do Cardoso, apesar de constarem no plano de manejo, desde 2002, não têm sido liberadas nos últimos anos. Tampouco existem procedimentos interinstitucionais estruturados para viabilizar tais demandas das comunidades tradicionais, segundo o Entrevistado 12.

As atividades ligadas à economia solidária praticada por coletivos de mulheres vêm sendo pesquisadas dentro da categoria de resistência cotidiana. O MAE estruturado a partir de três frentes geradoras de renda: artesanato e confecção (a partir de 2010), turismo comunitário e peixe seco e beneficiamento de produtos da pesca (ambos a partir de 2015) possui características de empreendimentos da economia solidária. Freire (2017) trabalhou com cinco grupos de economia solidária no estado de São Paulo, concluindo que “[...] é possível perceber que a economia solidária alterou o cotidiano e as relações dessas mulheres com a sociedade" (FREIRE, 2017, p. 17). Entre os aspectos positivos comuns a todas, estão: a) geração de renda por atividade valorizada por cada integrante; b) busca por conhecimento e formação; c) postura mais ativa, solidária e cidadã, em relação à política e articulações. E como, aspectos negativos comuns: i) permanência em atividades tradicionalmente femininas (como costura e alimentação); ii) falta de estabilidade financeira dos empreendimentos econômicos solidários; iii) dificuldade de formalização devido a legislação; iv) dificuldades em desenvolver as atividades, por permanecerem com a responsabilidade do cuidado com os filhos e com trabalho doméstico. 
O MAE, apesar de abarcar diversificadas atividades, é tido como uma das frentes da Associação de Moradores. A AMEB que tem mulheres nos principais cargos, se amplia com o processo de resistência para a permanência na Ilha do Cardoso. Em encontro realizado em abr./2019, foram reconhecidas como frentes de trabalho desta Associação: o Mulheres Artesãs da Enseada da Baleia (MAE), os mutirões comunitários, um projeto junto à Caixa Econômica Federal, palestras, a participação no Conselho Consultivo do PEIC, a estufa de secos e defumados, o fundo com moradores, a captação de água potável vinda da RESEX da Ilha do Tumba, uma festa proposta para junho, o tanque de evapotranspiração (TEvap) para tratamento de águas sanitárias, as pesquisas em andamento e a mobilização de novos recursos. Estas ações não são tocadas apenas por mulheres, mas acompanham o andamento de todas as frentes.

Viver em uma comunidade tradicional, por si só é um ato de resistência que depende significativamente da organização dos integrantes que a compõem. Na ausência desta organização, ocorrem as resistências cotidianas, que demonstram caminhos para a compreensão do pluriverso, proposto por Escobar $(2013,2015)$. À medida que as regras, acordos e legislações não dão conta de proteger as diferentes formas de existência, elas simplesmente ocorrem no cotidiano caiçara, com maior ou menor consciência sobre seus riscos.

\section{Considerações finais}

Em função de suas parcerias com organizações do terceiro setor e a participação em movimentos sociais ligados à Economia Solidária Feminista, as mulheres que compõe o MAE desenvolveram novas habilidades profissionais (administração, mobilização de recursos, comunicação etc.), motivando o processo de organização comunitária dentro dos valores da economia solidária e desempenhando papéis e ações fundamentais para o processo de resistência para a permanência na Ilha do Cardoso. Ocupam, até hoje, os cargos de Diretoria da Associação de Moradores da Enseada da Baleia (AMEB), dentro da qual mantêm uma relação de meio para o trabalho comunitário e não como um espaço de poder centralizado ou com hierarquias. Estas ações tendem a coexistir com práticas de reciprocidade (NASCIMENTO, 2015) e autonomia, que segundo Porto-Gonçalves (2006), são características dos povos e comunidades tradicionais, observados em momentos diversos, como nos mutirões semanais que viabilizaram a construção da Nova Enseada.

A dinâmica criada para viabilizar o MAE como empreendimento da economia solidária permitiu, por exemplo, que suas integrantes acessassem a Defensoria Pública do Estado de São Paulo para a propositura da única ação judicial que tramita neste caso, através da AMEB; buscassem apoio 
para a realização de etnomapeamento, que resultou na propositura da área da atual Nova Enseada; fizessem parte da organização estratégica e comunicação, participando de sete dos oito encontros e campanhas para a mobilização de recursos voltados à realocação; e, participassem diretamente da maior parte das 87 matérias jornalísticas feitas sobre o caso, desde o ano de 2011. No caso das parcerias, as mulheres não são as únicas responsáveis, mas participaram ativamente não apenas das negociações. Se não fosse o fato de desenvolverem novas habilidades e manterem fortes relações com agentes externos a comunidade, talvez não fosse possível praticar parte das vias de resistência descritas, pois estas vias demandaram negociação, parcerias consistentes e variadas, além de habilidade para lidar com a documentação necessária para que fosse exitosa a realocação da comunidade, mostrando que para que a tradição tivesse possibilidades de r-existir ${ }^{21}$, ela passou por processos de renovação, adaptação e ajustamento às novas realidades.

Apesar disso, as integrantes do MAE não se veem como protagonistas da história, mas como parte de uma triste jornada, cheia de perdas de familiares, que pouco a pouco vem se reafirmando como uma escolha de mudança acertada. Esta iniciativa dialoga com o conceito de "feminismo comunitário", proposto por Paredes (2014), que se diferencia do feminismo ocidental, ao pontuar que "partem da comunidade como princípio includente que cuida da vida", ao invés de basear-se na igualdade e diferença frente aos homens. Que partiriam de suas próprias realidades para "pensarmos mulheres e homens em relação à comunidade", com igualdade e respeito mútuo, complementaridade sem hierarquias. Tendo a compreensão que por comunidades, entendem a sociedade, "todo o grupo humano pode fazer e construir comunidades". Reconhecendo a alteridade, ou seja, reconhecendo as diferenças e diversidades da humanidade, além de que, querem ser reconhecidas como a metade de sociedade (PAREDES, 2014, p. 78-85, tradução nossa). No caso estudado, muitos dos princípios que diferenciariam o feminismo comunitário do feminismo ocidental, corroboram com a forma em que se organiza e resiste o MAE, em favor da comunidade da Enseada e dos direitos territoriais para permanecerem na Ilha.

Por fim, sem esgotar as reflexões que emergem deste estudo, refletindo sobre o complexo caso de resistência caiçara, faz-se significativo defender outro conceito como aglutinador de casos revelador de semelhanças e diferenças em si mesmo, que é o de reforçar a necessidade de que "outros mundos sejam possíveis" através do conceito de "pluriverso" (ESCOBAR, 2015), corroborando com a ideia de que um mundo hegemônico, pressiona para a invisibilidade e condena ao desaparecimento iniciativas comunitárias que se baseiam em peculiaridades territoriais, culturais, sociais e históricas

\footnotetext{
${ }^{21}$ Porto-Gonçalves cunha este conceito para designar aqueles movimentos sociais que não lutam apenas para resistir aos que dominam e estigmatizam, mas também para uma determinada forma de "existência", que inclui o modo de vida, produção e por pensar, sentir e agir também a seu modo (CRUZ, 2013).
} 
que não se enquadrem naquilo que se entende por modernidade. Esta pesquisa é mais uma oportunidade de dar visibilidade a uma pequena parte da história vivenciada pela Enseada da Baleia/Nova Enseada, buscando refletir teoricamente sobre a r-existêcia, nos termos de Porto Gonçalves, de uma comunidade tradicional de onze famílias. Concordando que o pluriverso é um caminho para reconhecer como possível e replicável iniciativas comunitárias como esta, assume-se que também seja viável um mundo que reconheça a existência de outros mundos, em uma natural correspondência à diversidade da vida.

\section{Referências}

ACSERALD, H. (Org.) Cartografias sociais e território. Rio de Janeiro, Instituto de Pesquisa e Planejamento Urbano e Regional, 2008. Disponível em: <www.ettern.ippur.ufrj.br/central_download.php?hash...id=8 >. Acesso em: 20 mar. 2018.

ACSELRAD, H.; COLI, L. R. Disputas cartográficas e disputas territoriais. In: ACSERALD, H. (Org.) Cartografias sociais e território. Rio de Janeiro, Instituto de Pesquisa e Planejamento Urbano e Regional, 2008. Disponível em: 〈www.ettern.ippur.ufrj.br/central_download.php?hash...id=8 > Acesso em: 20 mar. 2018.

ALIER, J. M. O Ecologismo dos Pobres. São Paulo: Contexto, 2007.

ALMEIDA, A. W. B. Terras tradicionalmente ocupadas: processos de territorialização e movimentos sociais. R. B. Estudos Urbanos e Regionais. São Paulo, v. 6, n. 1, p. 9 - 32, mai./2004. Disponível em: <http://rbeur.anpur.org.br/rbeur/article/view/102>. Acesso em: 03 jun. 2019.

ALMEIDA, A. W. B. Terra de quilombo, terras indígenas, "babaçuais livre", "castanhais do povo", faxinais e fundos de pasto: terras tradicionalmente ocupadas. 2. ed. Manaus: PCSCAUFAM, 2008. Disponível em: <http://www.ppgcspa.uema.br/wp-content/uploads/2017/07/AlfredoWagner-B-de-Almeida_Terras-Tradicionalmente-Ocupadas.pdf $>$. Acesso em: 20 mar. 2018.

ASSOCIAÇÃO REDE CANANÉIA. Notícias, Cananéia, 2014-2018. Disponível em: <http://www.redecananeia.org.br/>. Acesso em: 16 jan. 2019.

BALDIN, N.; MUNHOZ, E. M. B. Snowball (bola de neve): uma técnica metodológica para pesquisa em educação ambiental comunitária. In: Congresso Nacional de Educação, 10., 2011, Curitiba; Seminário Internacional de representantes sociais, subjetividade e educação, 1., 2011, Curitiba. Anais... Curitiba: Pontifícia Universidade Católica do Paraná, 2011. p. 329 - 341. Disponível em: <http://educere.bruc.com.br/CD2011/pdf/4398_2342.pdf>. Acesso em: 18 mar. 2018.

BASCHET, J. Resistencia, rebelión, insurrección. In: CASANOVA, P. G. (Dir.). Conceptos y fenómenos fundamentales de nuestro tempo. Ciudad de México: Universidade Nacional Autónoma de México, 2012. Disponível: 〈http://conceptos.sociales.unam.mx/conceptos_final/487trabajo.pdf〉. Acesso em: 20 mar. 2018. 
BENFEITORIA. Ajude a Nova Enseada. 2016. Disponível em: <https://benfeitoria.com/ajudeanovaenseada >. Acesso em: 15 dez. 2018.

BRASIL. Constituição (1988). Constituição: República Federativa do Brasil. Brasília, DF: Senado Federal, 1988.

BRASIL. Decreto de 13 de julho de 2006. Altera a denominação, competência e composição da comissão nacional de Desenvolvimento Sustentável das Comunidades Tradicionais e dá outras providências. Diário Oficial [da] República Federativa do Brasil, Brasília, 2006. Disponível em: <www.planalto.gov.br/ccivil_03/_Ato2004-2006/2006/Dnn/Dnn10884.htm>. Acesso em: 12 dez. 2018.

BRASIL. Decreto $\mathbf{n}^{0}$ 8.750, de 9 de maio de 2016. Institui o Conselho Nacional dos Povos e Comunidades Tradicionais. Diário Oficial [da] República Federativa do Brasil, Brasília, 2016. Disponível em: 〈www.planalto.gov.br/ccivil_03/_Aro2015_2018/2016/Decreto/D8750.htm\#art20 > Acesso em: 12 dez. 2018.

BRASIL. Decreto de 9.759, de 11 de abril de 2019. Extingue e estabelece diretrizes, regras e limitações para colegiados da administração pública federal. Diário Oficial [da] República Federativa do Brasil, Brasília, 2019. Disponível em: <www.planalto.gov.br/ccvil_03/_Ato20192022/2019/decreto/D9759.htm>. Acesso em: 20 jun. 2019.

CAMPOLIM, M. B.; PARADA, I. L. S.; YAMAOKA, J. G. Gestão participativa da visitação pública na Comunidade do Marujá - Parque Estadual da Ilha do Cardoso. In: IF Série Registros, n. 33, p. 39 - 49. São Paulo: Instituto Florestal, 2008. Disponível em: <http://www.iflorestal.sp.gov.br/RIF/SerieRegistros/IFSR33/IFSR33_39-49.pdf>. Acesso em: 16 jul. 2017.

CARVALHO, M. C. P.; SCHMITT, A. Relatório técnico-científico para identificação de famílias tradicionais presentes no Parque Estadual da Ilha do Cardoso. São Paulo, 2012. Disponível em: <http://www.geografia.fflch.usp.br/graduacao/apoio/Apoio/Apoio_Sueli/2s_2015/Biogeografia/Lau do_Antropologico_PEIC.pdf $>$. Acesso em: 29 jan. 2018.

CRUZ, V. C. Das lutas por redistribuição de terra às lutas pelo reconhecimento de territórios: uma nova gramática das lutas sociais? In: ACSELRAD, H. (Org.). Cartografia social, terra e território. 1. Rio de Janeiro: IPPUR/UFRJ, 2013, v. 1, p. 119-176.

DEPESP - DEFENSORIA PÚBLICA DO ESTADO DE SÃO PAULO (DEP-SP). Ação civil pública, com pedido liminar de reparação de danos materiais emergentes. Registro, SP. 84 p. Disponível em: <https://racismoambiental.net.br/wp-content/uploads/2016/12/ACP-ENSEADADA-BALEIA.pdf>. Acesso em: 16 dez. 2017.

DIEGUES, A. C. O mito moderno da Natureza Intocada. $3^{\text {a }}$ ed. São Paulo: Hucitec, 2001. Disponível em: <https://raizesefrutos.files.wordpress.com/2009/09/diegues-o-mito-moderno-danatureza-intocada.pdf $>$. Acesso em: 16 out. 2017.

ESCOBAR, A. La alternativa al modelo hegemónico de desarrollo capitalista es el concepto del buen vivir. Con nuestra América, Costa Rica. 23 nov. 2013. Entrevista. Disponível em: 
<https://connuestraamerica.blogspot.com.br/2013/11/arturo-escobar-la-alternativa-al-modelo.html $>$. Acesso em: 01 fev. 2018.

ESCOBAR, A. Territorios de diferencia: la ontogía política de los "derechos al território", Desenvolvimento Meio Ambiente, Curitiba, v. 35, p. 89-100, dez. 2015. Disponível em: <https://revistas.ufpr.br/made/article/view/43540>. Acesso em: 20 fev. 2019.

ESCOBAR, A. Sentipensar con la tierra: Las luchas Territoriales y la Dimension Ontologica de las Epistemologias del Sur. Revista de Antropologia Iberoamericana. Madrid, v. 11, n. 1, p. 11 - 32, 2016. Disponível em: 〈http://www.aibr.org/antropologia/netesp/numeros/1101/110102.pdf >. Acesso em: 18 nov. 2017.

ESTEVA, G. Desenvolvimento. In: SACHS, W. (Ed.) Dicionário do desenvolvimento: guia para o conhecimento como poder. [Tradução de: JOSCELYNE, V.L.M.; GYALOKAY, S.; CLASEN, J.A.] Petrópolis: Vozes, 2000. Título original: The development dictionary.

FRASER, N. Da redistribuição ao reconhecimento? Dilemas da justiça numa era "pós-socialista". [Tradução de: SIMÕES, J. A.] Cadernos de Campo. São Paulo, n 14/15, p. 231-239, 2006. Título original: From redistribution to recognition? Dilemmas of justice in a 'postsocialist' age.

FREIRE, A. P. V. Mulheres na Economia Solidária: resistência cotidiana por uma nova cidadania. 293 p. Dissertação (Mestrado em Ciência) Programa de Pós-Graduação em Mudança Social e Participação Política, Escola de Artes, Ciência e Humanidades, Universidade de São Paulo, São Paulo, 2017. Disponível em: <http://www.teses.usp.br/teses/disponiveis/100/100134/tde-13112017182410/pt-br.php>. Acesso em: 22 mar. 2018.

GOHN, M. G. Movimentos sociais na contemporaneidade. Revista Brasileira de Educação, v. 16, n. 47, p. 333-513, mai.-ago. 2011. Disponível em: <http://www.scielo.br/pdf/rbedu/v16n47/v16n47a05.pdf>. Acesso em: 04 fev. 2019.

HAYAMA, A. T.; CARDOSO, T. M. Comunidades caiçaras da Ilha do Cardoso, Conflitos Socioambientais e Refugiados da Conservação. In: JUBILUT, L. L. et al. Refugiados ambientais. Boa Vista: Ed. Universidade Federal de Roraima, 2018. p. 607 - 638.

HOBSBAWN, E. A era dos extremos - o breve século XX, 1914-1991. São Paulo: Cia das Letras, 1995.

LITTLE, P. E. Territórios sociais e povos tradicionais no Brasil: por uma antropologia da territorialidade. Anuário Antropológico/2002-2003, Rio de Janeiro: Tempo Brasileiro, p. 251 - 290, 2004.

Disponível

em:

<http://www.dan.unb.br/images/pdf/anuario_antropologico/Separatas\%202002-2003/2002-

2003 paullittle.pdf $>$. Acesso em: 20 mar. 2018.

LITTLE, P. E. Gestão territorial em terras indígenas: Definição de conceitos e proposta de diretrizes. Rio Branco: Universidade de Brasília, 2006. Relatório final.

MAFRA, T. V. Produção socioespacial do litoral do Paraná e as estratégias de resistências dos pescadores artesanais na luta pelo seu território. 355 p. Tese (Doutorado em Meio Ambiente e 
Desenvolvimento) - Programa de Pós-Graduação em Meio Ambiente e Desenvolvimento, Setor PróReitoria de Pesquisa e Pós-Graduação, Universidade Federal do Paraná, Curitiba, 2018.

MDS - MINISTÉRIO DO DESENVOLVIMENTO SOCIAL E COMBATE A FOME. Guia de políticas sociais $\quad$ Quilombolas. $2009 . \quad$ Disponível $\quad$ em: http://www.mds.gov.br/webarquivos/publicacao/assistencia_social/Guia/Guia_de_Politicas_Sociais _Quilombolas.pdf>. Acesso em: 20 mar. 2018.

MMA - MINISTÉRIO DO MEIO AMBIENTE. Instrução Normativa MMA no 15, de 16 de junho de 2005. Estabelese normas, critérior e padrões para a pesca de juvenis das espécies Anchoa marinii, Anchoa tricolor e Anchoa lyolepsis, conhecidas popularmente como "manjuba ou iriko", e as nomenclaturas regionais. Brasília, 2005. Disponível em: $<$ http://www.icmbio.gov.br/cepsul/images/stories/legislacao/Instrucao_normativa/2005/in_mma_15 _2005_normascriteriosparapescamanjuba_sp_pr.pdf >. Acesso em 10 fev. 2019.

NASCIMENTO, E. C. Malhas da reciprocidade: a pesca coletiva da Tainha na Ilha do Mel. 149 p. Dissertação (Mestrado em Desenvolvimento Territorial Sustentável) - Programa de Pós-Graduação em Desenvolvimento Territorial Sustentável, Universidade Federal do Paraná, Matinhos, 2015. Disponível em: < https://acervodigital.ufpr.br/bitstream/handle/1884/41953/R\%20-\%20D\%20\%20EVANDRO\%20CARDOSO\%20DO\%20NASCIMENTO.pdf? sequence=3\&isAllowed $=\mathrm{y}>$.

Acesso em: 16 fev. 2019.

NUPAUB - NÚCLEO DE APOIO À PESQUISA SOBRE POPULAÇÕES HUMANAS EM ÁREAS ÚMIDAS DO BRASIL. Laudo Técnico de avaliação da área de reassentamento da comunidade de Enseada da Baleia sob os aspectos antropológicos, ambientais e segurança geológica diante do processo erosivo na Ilha do Cardoso/Cananéia-SP. São Paulo, 2016. 94 p. Relatório técnico.

OIT - ORGANIZAÇÃO INTERNACIONAL DO TRABALHO. Convenção no 169 sobre povos indígenas e tribais e Resolução referente à ação da OIT. Brasília: OIT 2011. Disponível em: <http://portal.iphan.gov.br/uploads/ckfinder/arquivos/Convencao_169_OIT.pdf>. Acesso em 03 jun. 2019.

PAREDES, J. Hilando Fino: desde el feminismo comunitário. 2. ed. Mexico, 2014. Disponível em: $<$ https://sjlatinoamerica.files.wordpress.com/2013/06/paredes-julieta-hilando-fino-desde-elfeminismo-comunitario.pdf $>$. Acesso em: 10 nov. 2017.

PARQUE ESTADUAL DA ILHA DO CARDOSO. Conselho Consultivo do Parque Estadual da Ilha do Cardoso. Cananéia. Ata da $153^{\mathrm{a}}$ reunião realizada no dia 26 jul. 2011.

PORTO-GONÇALVES, C. W. A reinvenção dos territórios: a experiência latino-americana e caribenha. In: CECEÑA, A. E. Los desafios de las emancipaciones em um contexto militarizado. Buenos Aires: CLACSO, Consejo Latinoamericano de Ciencias Sociales, 2006. p. 151 - 197. Disponível em: <http://biblioteca.clacso.edu.ar/clacso/gt/20101019090853/6Goncalves.pdf > Acesso em: 04 fev. 2018.

PORTO-GONÇALVES, C.W.; HOCSMAN, L. D. (Orgs.). Despojos y resistencias em America Latina, Abya Yala. Cuidad Autónoma de Buenos Aires: Estudios Sociológicos Ed., 2016. Disponível em: $\quad<$ http://estudiosociologigicos.org/-descargas/eseditora/despojos-y-resistencias/despojos-yresistendias-en-america-latina_portogoncalves.pdf $>$. Acesso em: 20 mar. 2018. 
RODRIGUEZ, J. M. M.; SILVA, E. V. Educação Ambiental e Desenvolvimento Sustentável: Problemáticas, Tendências e Desafios. 4. ed. Fortaleza: Editora UFC, 2016.

SANTOS, C. S. Acesso à justiça no Brasil: notas sobre o modelo de serviço legal da Defensoria Pública. Revista Brasileira da Sociologia do Direito, v. 3, n. 2, mai.-ago. 2016. p. 130 - 145. Disponível em: 〈http://revista.abrasd.com.br/index.php/rbsd/article/view/59/80 >. Acesso em: 05 fev. 2019.

SÃO PAULO (Estado). Decreto n ${ }^{\circ} 40.319$, de 03 de julho de 1962. Dispõe sobre a criação do Parque Estadual da Ilha do Cardoso, em Cananéia. Legislação do Estado de São Paulo, São Paulo, 1962. Disponível em: <http://www.al.sp.gov.br/repositorio/legislacao/decreto/1962/decreto-4031903.07.1962.html>. Acesso em: 14 ago. 2017.

SÃO PAULO (Estado). Lei n ${ }^{\circ} 16.260$, de 29 de junho de 2016. Autoriza a Fazenda do Estado a conceder a exploração de serviços ou o uso, total ou parcial, de áreas em próprios estaduais que especifica e dá outras providências correlatas. Diário Oficial do Estado de São Paulo, São Paulo, 2016. Disponível em: < https://www.al.sp.gov.br/repositorio/legislacao/lei/2016/lei-1626029.06.2016.html>. Acesso em: 20 nov. 2018

SCOTT, J. C. Exploração normal, resistência normal. Revista Brasileira de Ciência Política, n. 5. Brasília, jan. - jul. 2011. p. $217-234$ - Disponível em: <http://www.scielo.br/scielo.php?script=sci_arttext\&pid=S0103-33522011000100009>. Acesso em 20 mar. 2018.

SÉRIE COMUNIDADE CAIÇARA/ PROG. 3 - ENSEADA DA BALEIA / BLOCO 2. Universidade Unifieo. Osasco: Unifieo, 2009. 12’38. Disponível em: <https://www.youtube.com/watch?v=9WA275yIMDQ>. Acesso em 14.ago.2017.

SILVA, E. M. S. et al. Guia de Elaboração de Pequenos Projetos Socioambientais para Organizações de Base Comunitária. Brasília: Instituto Sociedade, População e Natureza, 2014. Disponível em: 〈http://www.ispn.org.br/livrocapta/>. Acesso em: 06 fev. 2019.

VALLE, P. F. Conflitos e possibilidades da participação de comunidades locais na gestão do Parque Estadual da Ilha do Cardoso, São Paulo. 192 f. Dissertação (Mestrado em Ciências) Programa de Pós-Graduação em Mudança Social e Participação Política - Escola de Artes, Ciências e Humanidades, Universidade de São Paulo, São Paulo, 2016. Disponível em: <http://www.teses.usp.br/teses/disponiveis/100/100134/tde-31102016-150455/pt-br.php>. Acesso em: 20 nov. 2018.

VIOLA RECASENS, A. Usos y abusos del concepto de resistencia: um balance crítico del debate en torno a la obra de James Scott. In: LAVIÑA, J.; OROBITG, G. (Coord.). Resistencia y territorialidad culturas indígenas y afroamericanas. Barcelona: Universitat de Barcelona, 2008.

Artigo recebido em 22/04/2019. Aceito para publicação em 26/06/2019. 